\title{
Trajectories of development of state-owned banks by analyzing the dynamics of patterns
}

\author{
Amina Mussina \\ Doctor of Economic Sciences, Docent, Professor, Banking Department, Director, Center for Social \\ and Economic Research, Kazakh University of Economics, Finance and International Trade, Astana, \\ Republic of Kazakhstan
}

\section{Inna Shkolnyk}

Doctor, Professor, Head of Department of Finance, Banking Management and Insurance, Sumy State University, Ukraine

\section{Alina Bukhtiarova}

Ph.D. in Economics, Senior Lecturer of Department of Finance, Banking Management and Insurance, Sumy State University, Ukraine

\begin{abstract}
The article investigates the trajectory of state-owned banks by analyzing the patterns on the example of stateowned banks in Ukraine. The trajectory of the evolution of the state-owned banks can be defined ordered set of patterns, each of which describes the activities of the bank at a concrete moment of the time. The experience of state-owned banks in differently countries around the world was considered. To assess the state-owned banks in Ukraine for the period 2007-2016 the authors offer to assess the dynamics model of patterns of stateowned banks based on Kohonen self-organizing maps and cluster analysis. The model includes 14 indicators providing input variables of model formation. Also it comprises 35 banks of Ukraine, which has been operated during 2007-2016, including 7 state-owned banks. The authors proved that the Ukrainian state-owned banks are essentially commercial banks and non-state agents of a special mission, recently transformed into an additional burden for the state budget.
\end{abstract}

Keywords: banks, Harrington desirability function, cluster analysis, self-organizing map, pattern of bank.

JEL Classification: G21, G32.

\section{Introduction}

Nowadays there is no single position on the need for state-owned banks. There are countries where banking systems have exclusively private banks and countries where state banks dominate and vice versa. It also does not depend on the level of economic development, as well as the others have different examples.

Onishchenko V. researched the operation of state-owned banks in the banking system which allowed to distinguish the banking systems of countries with different levels of state involvement in the bank: 1) restricted (Austria, Poland, Switzerland, Germany); 2) with high level (China, Russia, India, Brazil, France, Argentina, Thailand, Indonesia, Malaysia, the Philippines, Taiwan, Romania); 3) where increasing state presence was a necessary response to banking crises (Spain, Finland, Latvia, Hungary, Ukraine, Chile, Mexico, South Korea, Arhen- fences, Egypt, Mauritania, Tanzania) [9].

As of January 1, 201635 banks operated in the banking system of Kazakhstan. They are all private [1]. But at the same time there is a state bank "Development Bank of Kazakhstan" which has a special status, which gives him the following advantages: the lack of regulation of certain bank operations from the National Bank of Kazakhstan, the possibility to use the authorized capital for lending. In fact, the bank is a leader of the state to support the development of industrial infrastructure and manufacturing, it improves the efficiency of public investment, attracts foreign and domestic investments in the economy; the country's leading operator for evaluation and structuring of large infrastructure and industrial projects for the private sector and the Government of the Republic of Kazakhstan. According to the mandate of the Development Bank, the main sectorial priorities are the projects in non-primary sectors of the economy: metallurgy, chemistry and petro chemistry, mechanical engineering, processing specialized state development institution that provides timely and sufficient 
funding of projects in the field of industry and infrastructure; a financial institution to provide the best financing in local currency; one of the largest financial institutions in Kazakhstan in terms of assets with recognized competence in international markets; a main agent on attracting long-term and low-cost loans and investments for corporate clients. At the end of 2015, the volume of the Development Bank's loan portfolio amounted to 1452 billion tenge, or $96 \%$ compared to the total amount of the actual debt on loans of second-tier banks, aimed at long-term lending to non-primary sectors of the economy [2].

At the same time, if we consider the banking system in Germany, the state banks perform another functions and their share is quite significant. According to the Association of German Public Banks (Bundesverband Öffentlicher Banken Deutschlands, VÖB) the number of participants is 63 banks, the share of these banks is $34 \%$ of the market [3]. But they are not vested with such powers as the Development Bank of Kazakhstan.

Regarding the banking system of Ukraine, according to the decision of the Committee on Oversight and regulation of banks supervision (oversight) of payment systems as of December 31, 2015 № 657 (as amended) the allocation of banks in Ukraine in the group of banks with a state share in 2016 was classified as: JSC "Oschadbank", JSC “Ukreximbank", JSB "Ukrgasbank", OJSC "Rodovid Bank", PJSC "Payment Center", PJSC "Derzhzembank", OJSC "The Ukrainian Bank for Reconstruction and Development". On the basis of the resolution of the National Bank of Ukraine as of December 25, 2016 № 107 OJSC "Rodovid Bank" was classified as an insolvent bank. According to the decision of the National Bank of Ukraine September 27, 2016 № 302 began liquidation procedure of the PJSC "Derzhzembank”.

On December 18, 2016 the Government of Ukraine decided to nationalize 100\% of shares of PJSC "CB Privatbank". Thus, in 2017 PJSC "CB Privatbank" and was included into the first group of banks (banks in which the state directly or indirectly owns over $75 \%$ of the share capital). Considering that PJSC "CB Privatbank" and PJSC "Oschadbank" compromise the largest network of bank branches and the largest customers' bases of both physical and legal entities important innovative approaches for assessing the status and prospects of functioning of state banks are acquired. The works of of Karas, A., Schoors, K., Weill, L., Zarutska, O., Kozmenko, S., Vitlinsky, V., Verchenko, P., Sigal, A., Nakonechny, Y., Krupka, M., Heinz, R., Kulpinska, L., Kohonen, T., Vasileva, T. are devoted to the research of state-owned banks and the use of dynamic analysis of patterns of behavior of banks.

The activity of state-owned banks were formed in accordance with the mission entrusted to them by the state the functions of the financial agent of government, lending base and promising sectors of the national economy, providing population with reliable financial instrument guaranteed savings, which requires balanced, even conservative politicians. On the other hand, state participation in the authorized capital gives banks guaranteed access to sources of refinancing and maintenance budget, providing leading position in the government and corporate securities transactions with T-bills, which, to some extent, weakening their innovative activity. Guaranteed access can be regarded as an opportunity to obtain the necessary financial security to innovation, but today more as a potential [4].

The banking system of Ukraine has significantly changed its configuration after the decision of the Government of Ukraine as of December 18, 2016 to nationalize 100\% of shares of PJSC "CB Privatbank". Inclusion of this bank to the first group of banks (banks with state participation) has led to a significant increase in the share of state-owned banks in terms of assets as well as the size of liabilities. Construction of clusters is based on the similarity among banks selected for the study parameters/factors. Group indicators characterizing a single cluster is called a pattern. In practice, each cluster has its own unique pattern, which it describes. Changing the dynamics of patterns may indicate a change in the strategic objectives of the bank. The study of the dynamics of patterns and their temporal characteristics can be a tool to assess the evolution of the bank and will predict individual performance of the bank development in the future.

\section{Methods}

A priority task for scholars and practitioners is the research and analysis of financial conditions of Ukrainian banks. The most common method of estimating the financial conditions is based on the analysis of certain financial ratios defined in the list. However, the quality of the results obtained in this study greatly affects the quality of input data, which is mainly concentrated in the financial statements of the bank.

We consider that the trajectory of the evolution of the bank can be defined as ordered set of patterns, each of which describes the activities of the bank at a time. It should be noted that the larger the range of indicators 
of the performance of the bank, the cluster analysis will be conducted more accurately, as an effective mechanism for building patterns prerequisite is a large amount of input data.

Kohonen self-organizing maps (SOM) is a neural network with learning opportunities and improvement in the mode "without a teacher" that perform the task of visualization and clustering. The idea of building the network was developed by Teuvo Kohonen, Finnish scientist, in 60s of the XXth century. Kohonen selforganizing maps act by designing multidimensional space into a space with lower dimension (often two-dimensional) used to solve problems of modeling, forecasting, and others. Details of the model used for the calculations are presented in the work of Kulpinska, L.K. (2013). To evaluate the banks in Ukraine for the period 2007-2016 we proposed a model for the assessment of the dynamics of banks' patterns based on Kohonen self-organizing maps and cluster analysis.

Stage 1. Defining the metrics on which the map is based on clusters.

The model has been used 14 indicators that provide the formation of input variables of the model.

Stage 2. Normalization of input data of the model.

The method determines the relative normalization method of defining ideal vector.

As an ideal vector we use the vector whose components are the maximum possible value of local criteria (equation 1).

$$
e_{q}^{\text {ideal }}=\left(\left(\max _{S_{i} S} e_{1}\left(s_{i}\right) ; \ldots ;\left(\max _{S_{i} S} e_{q}\left(s_{i}\right) ; \ldots\left(\max _{S_{i} S} e_{Q}\left(s_{i}\right)\right) .\right.\right.\right.
$$

Then we use the relative normalization method and calculate performance values:

$$
e_{q}^{H}\left(s_{k}\right)=\frac{e_{q}\left(s_{k}\right)}{\max _{S_{i} S} e_{1}\left(s_{i}\right)}, q=1, \ldots, Q ; k=1, \ldots, m .
$$

\section{Results}

Stage 3. Using the Harrington function optimization for input. To use the scale of Harrington function we need all the studied parameters lead to the dimensionless form according to the horizontal axis and calculate the value of partial functions of Harrington.

Particle coefficients, calculated coefficients in generalized systems, allow us to evaluate their advantages and disadvantages. If the ratio is a desirable system in the lower area which features a distortion of the Harrington function; to receive satisfactory results of the bank's functioning should "pull" almost all the parameters of the system to an acceptable level (due to the high cost of time and effort to be correctly estimate).

If the ratio of the system is based on a linear plot of $G=0.2$ to $G=0.8$, even a relatively small change in performance ratios (improved one or two parameters) can significantly increase its "desirability" and the possibility of further development of the bank very large.

When a system is generalized desirability factor of $0.8-0.9$, except that it is very good from the standpoint of desirability (for now), we can say that the bank is close to the limit of its development. Improving performance through its "improvement" (i.e., "pull" all settings at maximum) require excessively high costs and the need to look brand new ways of future development (Table. 1).

Thus, analyzing the desirability of partial factors of specific parameters can assess opportunities and ways of upgrading of individual bank.

Thus, in the convolution of the input data using the desirability of the Harrington function, 14 indicators included in the model formed four groups which are from the most significant to least significant: indicators of assets $\left(G_{a}\right)$, indicators of bank deposits $\left(G_{d}\right)$, indicators of capital bank $\left(G_{k}\right)$ and indicators of bank loans $\left(G_{k r}\right)$.

Stage 4. The process of data processing by means of Viscovery SOMine.

Stage 5. Evaluation of the adequacy of the model. To test the adequacy of the model, to introduce the study together, two conventional banks - the "good" and "bad" values of the parameters. Reaction model allows concluding correct response to the model of diametrically different value indicators. The result is a new map 
of Kohonen. Based on the results, added modeled banks show an adequate response to the models for different values of input.

As it was noted above, after the decision to nationalize PJSC "CB Privatbank", the configuration of the banking system of Ukraine has changed significantly. The share of assets in state-owned banks is over 50\%, indicating a high level of monopolization of the banking system, while three banks have a share of over $12 \%$ (see Figure 1 in Appendix).

The share of state-owned banks in the liabilities of banks in Ukraine is approximately the same proportions as the assets that have seen a similar situation in terms of monopolization, including the deposit market. Note that one of the biggest state-owned banks JSC "Oschadbank" is not a member of the Deposit Guarantee Fund of individuals, as it is responsible for its obligations by the state (Figure 2 in Appendix).

The analysis of other indicators of the state banks, especially the largest - PJSC "CB Privatbank", JSC "Savings Bank", JSC "Ukreximbank" and JSC "Ukrgasbank" demonstrated a high level of commercialization of their activity that in fact they operate like regular commercial banks. In this case, their actions cannot be considered as highly effective.

JSC "Oschadbank" and PJSC "CB Privatbank", and JSC "Ukreximbank" receive additional increase of equity capital by capitalization of the state, that banks continue to operate at the expense of taxpayers. For example, at the beginning of 2016 JSC "Oschadbank" received capitalization in the amount of 5 billion USD, JSC "Ukreximbank" -9.3 billion UAH. PJSC "CB Privatbank" was capitalized at the end of 2016.

On December 28, 2016 the National Securities Commission conducted registration of shares of PJSC "CB Privatbank " totaling 116.8 billion UAH with maturities until February 24, 2017.

The Ministry of Finance of Ukraine adopted the relevant decision on the issue of T-bills in the amount of UAH 64 billion (bonds indexed to the value of the US dollar) with a yield of 6\% per year and 43 billion ordinary government bonds with a yield of about $10 \%$.

Also, in 2017, it is planned to allocate funds from the budget for capitalization JSC "Oschadbank" at a rate of 3.5 billion UAH and JSC "Ukreximbank" - 3 billion UAH.

Thus, an additional burden on the budget to support the functioning of state banks in 2016 amounted to at least 130 billion USD, and already in 2017 comprised at least 6.5 billion UAH. For comparison, in 2016, according to the Ministry of Finance of Ukraine, total consolidated budget expenditures on education in Ukraine amounted to 120.4885 billion UAH.

Note that a regular maintenance of state-owned banks by the government does not guarantee the improvement of their performance as evidenced by the results shown in Table 2, Figure 3 (see in Appendix).

To assess the activity of banks in Ukraine for the period 2007-2016 we proposed a model for evaluating the dynamics patterns of banks based on Kohonen self-organizing maps and cluster analysis.

The model includes 35 Ukrainian banks: PJSC "Alfa-Bank", PJSC Bank "Arcada", PJSC "Bank Vostok", PJSC "Bank Credit Dnepr", PJSC "BTA Bank", PJSC "VTB Bank", PJSC "Eastern Ukrainian Bank "Grant", PJSC “Diamantbank", PJSC "Express Bank”, PJSC Commercial Bank "Zemelny Capital”, PJSC "Idea Bank", PJSC "ING Bank Ukraine", PJSC "Industrialbank", PJSC "Credit-Agricole Bank", PJSC "Commercial Industrial Bank", PJSC "Megabank», JSC “OTP Bank", PJSC "State Savings Bank of Ukraine", PJSC "Pivdennyi Bank", PJSC CB "Pravex-Bank", PJSC "CB Privatbank", PSC "Prominvestbank", PJSC "FUIB", PJSC "Raiffeisen Bank Aval", OJSC "Rodovid Bank", PJSC "Payment Center", PJSC "Citibank", OJSC "The Ukrainian Bank for Reconstruction and Development", PJSC "Bank "Ukrainian Capital", JSB "Ukrgasbank", JSC "Ukreximbank”, JSC "UkrSibBank", PJSC "Ukrsotsbank" (UniCredit Bank), PJSC "Universal Bank", PJSC "Finbank".

While constructing the model 14 indexes were used, which provide the formation of the model of input variables. Among the indexes, there are 2 absolute ones - assets size and the index of bank's financial result for an accounting year (attributable level) and 12 relevant indexes, which may characterize the efficiency of bank activity, in particular: bank liquidity, assets profitability, capital profitability, capital adequacy, ratio of loans to deposits, ratio of credits to assets, ratio of retail deposits to liabilities, ratio of deposits to liabilities, ratio of retail deposits to assets, ratio of deposits to assets, interest margin. 
The Fishburne rule executes the normalization of weighs and the calculations of weigh coefficients. To determine the weighs by this rule, it is necessary to place the groups from the most essential to the least essential. By analyzing all the groups, we may make a conclusion that the most essential from the position of providing the banking system stability is the group of indexes characterizing the assets state of bank $\left(G_{a}\right)$ (weigh coefficient of group is 0.4), then, the groups of indexes goes, characterizing the bank deposits state $\left(G_{d}\right)$ (weigh coefficient of group is 0.3 ) and bank's capital state $\left(G_{\kappa}\right)$ (weigh coefficient of group is 0.2 ). The least essential will be the group of indexes that characterize the state of bank credits $\left(G_{c r}\right)$ (weigh coefficient of group is 0.1). The Kohonen's map learns the parameters' setting. The determined quantity of nodes equals to 1000 of the Kohonen's map due to the size of total quantity of researched banks. The size of tension parameter is determined as 0.3 for growing delicacy of artificial neuron network. For getting more precise results we choose "Accurate" training schedule.

The results of cluster analysis is the general Kohonen's map shown in Figure 4 (see in Appendix).

The ranking method was used for the analysis and evaluation of each cluster (Table 3, see in Appendix).

Thus, based on received results, we make cluster ranking. To evaluate the activity efficiency of each separate bank, which was related to the definite cluster, we propose to separate clusters conveniently in groups (Table 4, see in Appendix).

Thus, by results interpretation we can form the trajectory of individual banks during 2007-2016 (Table 5, see in Appendix).

Thus, the results demonstrate the following picture. During the studied period JSC "Oschadbank" had unstable trajectory dynamics (Figure 5, see in Appendix), namely being a powerful bank at the beginning of the period under review was very negative effects of the financial crisis of 2008, the bank moved to a cluster of powerful stable banks. The economic and political crisis in 2014 led to a change of the trajectory of the bank and by the results of 2015 and 2016 the bank moved to a cluster of problem banks and the capitalization had no positive impact on the dynamics of its development.

During 2007-2014 JSC "Ukreximbank" had a stable trajectory, while in the cluster $S_{1}$ - stable banks and only crisis in 2014 had a negative impact on its position and moved it to a cluster of banks in crisis. However additional capitalization of the bank in 2016 was 9.3 billion USD. Facilitating the bank's movement in a cluster of problem banks shows a positive moment of development (Figure 6, see in Appendix).

The trajectory of JSC "Ukrgasbank" is quite chaotic, because in 2008 the bank was nationalized and the trajectory of its movement in many ways defined the government's decisions regarding its follow-up, demonstrating a decision on accession to the bank insolvent bank "Kyiv" in 2015, which significantly changed the trajectory of the bank and shifted it from the cluster $S_{1}$ of once stable banks in the cluster $S_{4}$ - banks in the crisis financial condition. For 2016 the bank showed a positive financial result. The decision of the Government recognized the object, which has a strategic importance for the economy and security of the state and further development strategy plans as Eco-Bank that will promote energy efficiency and energy independence of Ukraine (Figure 7, see in Appendix).

Regarding JSC "Rodovid Bank", the bank is now recognized as insolvent, confirming corresponding trajectory. Note that JSC "Rodovid Bank" because of the 2008 crisis was also nationalized, but unlike JSC "Ukrgasbank" the bank could not get out of the crisis of financial condition (Figure 8, see in Appendix).

Due to the inaccessibility for advanced analysis of financial statements of PJSC "Payment Center" study period was 3 years (2014 to 2016). Obviously, such a short period is not enough to analyze in detail the path of development, now the bank is in a cluster of problem banks, which may be typical for a bank that has not yet released the full strategic capacity of the assets and liabilities (Figure 9, see in Appendix).

OJSC "The Ukrainian Bank for Reconstruction and Development" was created to promote the development of innovation infrastructure in Ukraine, but throughout the entire period of its existence the bank is consistently located in a cluster of problem banks, and has little interest in the assets of the banking system and demonstrates the low performance of the activity (Figure 10, see in Appendix). 
Regarding PJSC "CB Privatbank", then it was nationalized in less than two months ago, but during the entire period analyzed bank is in a cluster of powerful banks, which is a leader in the banking system both in financial performance and in terms of manufacturability (Figure 11, see in Appendix).

\section{Results}

So, carried research enables us to several important conclusions about the role of state banks and the dynamics of their development. First, public banks play different roles and perform different functions in different countries, depending on the mission assigned to them by the state. Second, the claim that state-owned banks are a priori ineffective not because there are banks that demonstrate high financial results and some banks that are consistently unprofitable. Third, the Ukrainian state-owned banks are essentially commercial banks and nonstate agents of a special mission, recently transformed into an additional burden for the state budget. In this regard, it is appropriate to review the feasibility of storing state control.

\section{References}

1. Association of German Public Banks, VÖB. Retrieved from https://www.voeb.de.

2. Annual report (2015). Development Bank of Kazakhstan. Retrieved from http://www.dbk.kz/en/about/reports/.

3. Krupka, M. (2014). Financial innovation of state-owned banks Ukraine. Financial Space, 4(16), 127-131.

4. Heinz, R. (2009). State Financial Institutions: Mandates, Governance, and Beyond. World Bank Policy Research Working Paper, 5141.

5. Report of the National Bank of the Republic of Kazakhstan for 2015. Retrieved from http://www.nationalbank.kz/cont/Annual\%20Report_2015_3.pdf.

6. Karas, A., Schoors, K., and Weill, L. (2008). Are Private Banks More Efficient Than Public Banks? Evidence from Russia. BOFIT Discussion Papers 3, Bank of Finland, BOFIT Institute for Economies in Transition.

7. Kozmenko, S., Shkolnyk, I., Bukhtiarova, A. (2009). Dynamics patterns of banks evaluations on the basis of Kohonen self-organizing maps. Banks and Bank Systems, 4(1). doi: http://dx.doi.org/10.21511/bbs.11.

8. Kulpinska, L.K. (2013). Stimulating Investment Development through Transformation of State Banks Activity. Business Inform, 12, 297-301.

9. Onishchenko, V.V. (2012). Banks with state share in banking system of Ukraine. - Manuscript. Ph.D. Thesis.

\section{Appendices}

Table 1. Scale of assessment of the desirability of the Harrington function

\begin{tabular}{|c|c|}
\hline Desirability & Estimates on the scale of desirability \\
\hline Very kind & {$[0,80-1,00]$} \\
\hline Good & {$[0,63-0,80)$} \\
\hline Satisfactory & {$[0,37-0,63)$} \\
\hline Bad & {$[0,20-0,37)$} \\
\hline Very bad & {$[0,00-0,20)$} \\
\hline
\end{tabular}

Table 2. Net financial result of state owned banks Ukraine as of January 1, 2017, thousand UAH

\begin{tabular}{|l|c|}
\hline \multicolumn{1}{|c|}{ Bank } & Net financial result, thousand UAH \\
\hline PJSC “CB Privatbank" & -135928838 \\
\hline JSC “Oschadbank" & 1844957 \\
\hline JSC "Ukreximbank" & -932195 \\
\hline JSB "Ukrgasbank" & 696701 \\
\hline PJSC "Payment Center" & 2091 \\
\hline OJSC "UBRR” & -3520 \\
\hline OJSC "Rodovid Bank" & -193024 \\
\hline
\end{tabular}

Source: according to NBU. 
Table 3. Cluster ranking formation

\begin{tabular}{|c|c|c|c|c|c|c|c|}
\hline Cluster & Cluster share & $G_{1}$ & $G_{2}$ & $G_{3}$ & $G_{4}$ & Synthesis function & Ranking \\
\hline$S_{1}$ & $59.77 \%$ & 0.4758 & 0.4363 & 0.5296 & 0.5351 & 0.4942 & 2 \\
\hline$S_{2}$ & $21.57 \%$ & 0.4351 & 0.4465 & 0.4171 & 0.5098 & 0.4521 & 3 \\
\hline$S_{3}$ & $9.33 \%$ & 0.3992 & 0.3548 & 0.5276 & 0.5146 & 0.4491 & 4 \\
\hline$S_{4}$ & $3.50 \%$ & 0.3434 & 0.0914 & 0.5006 & 0.5474 & 0.3707 & 5 \\
\hline$S_{5}$ & $2.62 \%$ & 0.0417 & 0.1454 & 0.4748 & 0.4758 & 0.2844 & 6 \\
\hline$S_{6}$ & $3.21 \%$ & 0.5584 & 0.4454 & 0.6445 & 0.5403 & 0.5472 & 1 \\
\hline
\end{tabular}

Table 4. Cluster ranking

\begin{tabular}{|c|c|c|}
\hline Ranking place & Cluster & Groups of banks \\
\hline 1 & $S_{1}$ & Powerful banks \\
\hline 2 & $S_{2}$ & Stable banks \\
\hline 3 & $S_{3}$ & Problem banks \\
\hline 4 & $S_{4}$ & Banks in crisis \\
\hline 5 & $S_{5}$ & Banks at the stage of bankruptcy \\
\hline 6 & $S_{6}$ & \\
\hline
\end{tabular}

Table 5. Trajectory of development of state-owned banks in Ukraine in 2007-2016

\begin{tabular}{|l|c|}
\hline \multicolumn{1}{|c|}{ Bank } & Trajectory of development of bank \\
\hline JSC «Oschadbank» & $\mathrm{S} 6 \rightarrow \mathrm{S} 6 \rightarrow \mathrm{S} 1 \rightarrow \mathrm{S} 1 \rightarrow \mathrm{S} 1 \rightarrow \mathrm{S} 1 \rightarrow \mathrm{S} 1 \rightarrow \mathrm{S} 1 \rightarrow \mathrm{S} 3 \rightarrow \mathrm{S} 3$ \\
\hline $\mathrm{JSC} «$ Ukreximbank» & $\mathrm{S} 1 \rightarrow \mathrm{S} 1 \rightarrow \mathrm{S} 1 \rightarrow \mathrm{S} 1 \rightarrow \mathrm{S} 1 \rightarrow \mathrm{S} 2 \rightarrow \mathrm{S} 1 \rightarrow \mathrm{S} 1 \rightarrow \mathrm{S} 4 \rightarrow \mathrm{S} 3$ \\
\hline JSB «Ukrgasbank» & $\mathrm{S} 1 \rightarrow \mathrm{S} 1 \rightarrow \mathrm{S} 1 \rightarrow \mathrm{S} 5 \rightarrow \mathrm{S} 1 \rightarrow \mathrm{S} 5 \rightarrow \mathrm{S} 1 \rightarrow \mathrm{S} 1 \rightarrow \mathrm{S} 4 \rightarrow \mathrm{S} 1$ \\
\hline OJSC «Rodovid Bank» & $\mathrm{S} 1 \rightarrow \mathrm{S} 1 \rightarrow \mathrm{S} 1 \rightarrow \mathrm{S} 5 \rightarrow \mathrm{S} 5 \rightarrow \mathrm{S} 5 \rightarrow \mathrm{S} 2 \rightarrow \mathrm{S} 2 \rightarrow \mathrm{S} 2 \rightarrow \mathrm{S} 2$ \\
\hline $\mathrm{PJSC} \ll$ Payment Center» & $\mathrm{S} 2 \rightarrow \mathrm{S} 2 \rightarrow \mathrm{S} 2$ \\
\hline OJSC «UBRR» & $\mathrm{S} 2 \rightarrow \mathrm{S} 2 \rightarrow \mathrm{S} 2 \rightarrow \mathrm{S} 5 \rightarrow \mathrm{S} 2 \rightarrow \mathrm{S} 2 \rightarrow \mathrm{S} 2 \rightarrow \mathrm{S} 2 \rightarrow \mathrm{S} 2 \rightarrow \mathrm{S} 2$ \\
\hline PJSC «CB Privatbank» & $\mathrm{S} 6 \rightarrow \mathrm{S} 6 \rightarrow \mathrm{S} 6 \rightarrow \mathrm{S} 6 \rightarrow \mathrm{S} 6 \rightarrow \mathrm{S} 1 \rightarrow \mathrm{S} 6 \rightarrow \mathrm{S} 6 \rightarrow \mathrm{S} 6 \rightarrow \mathrm{S} 6$ \\
\hline
\end{tabular}

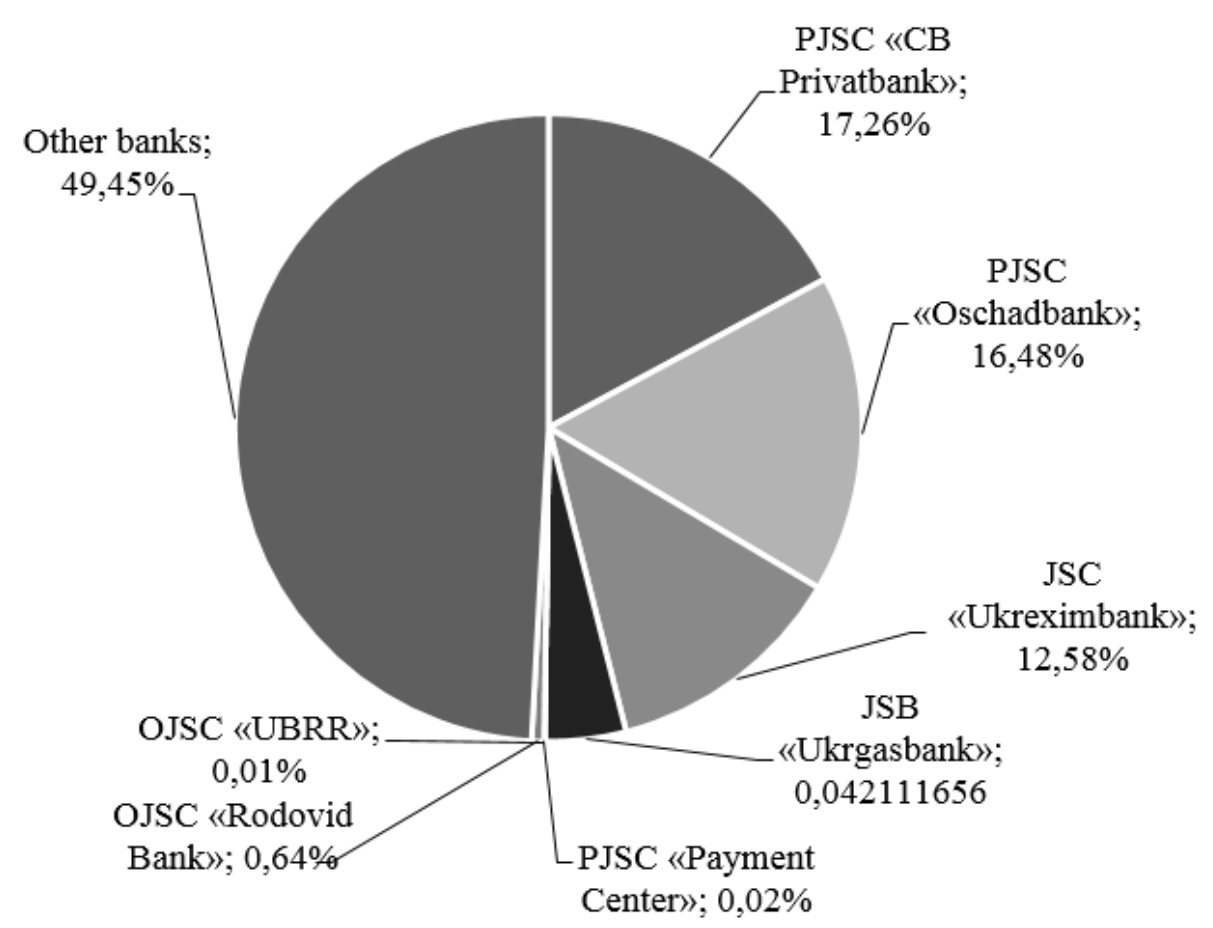

Figure 1. Share of assets of state-owned banks in the banking system of Ukraine as of January 1, 2017, \% 


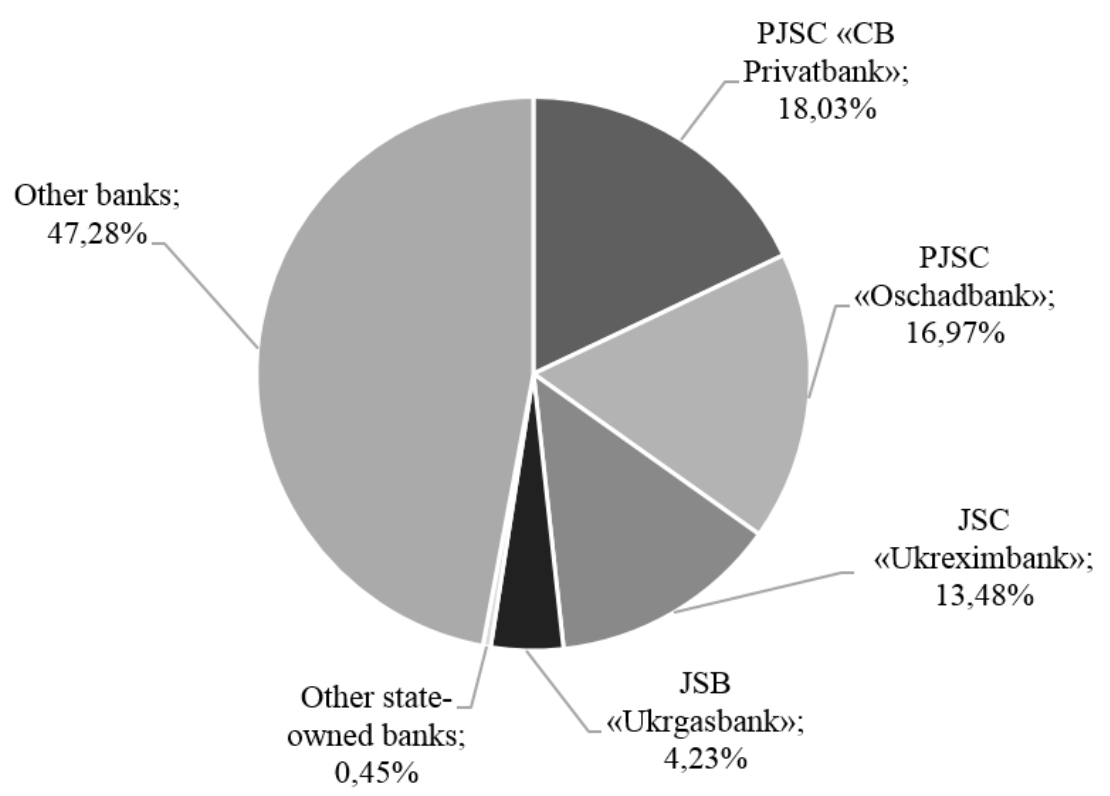

Figure 2. Share of liabilities of state-owned banks in the banking system of Ukraine as of January 1, 2017, \%

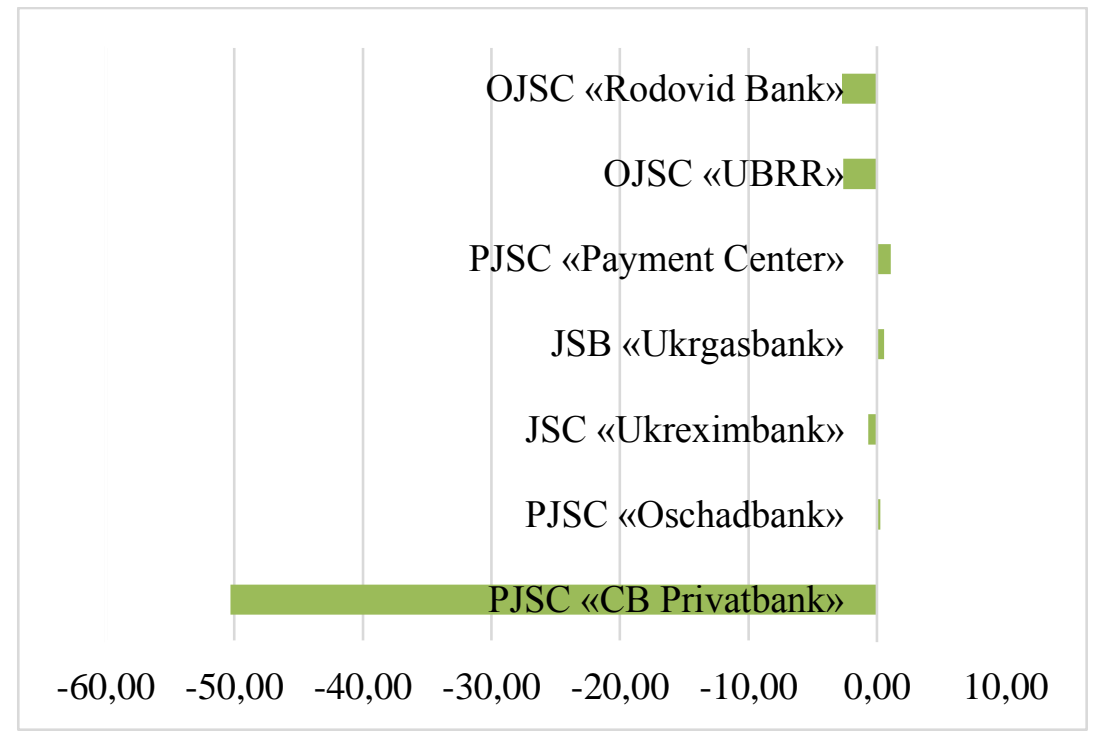

Figure 3. Return on assets of state banks in Ukraine as of January 1, 2017, \%

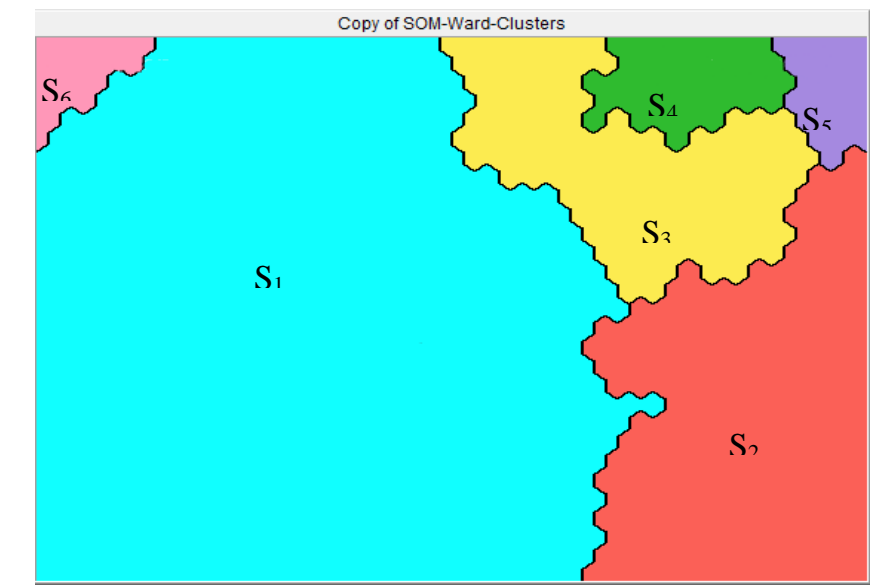

Source: authors' calculations based on data NBU.

Figure 4. General Kohonen's map 


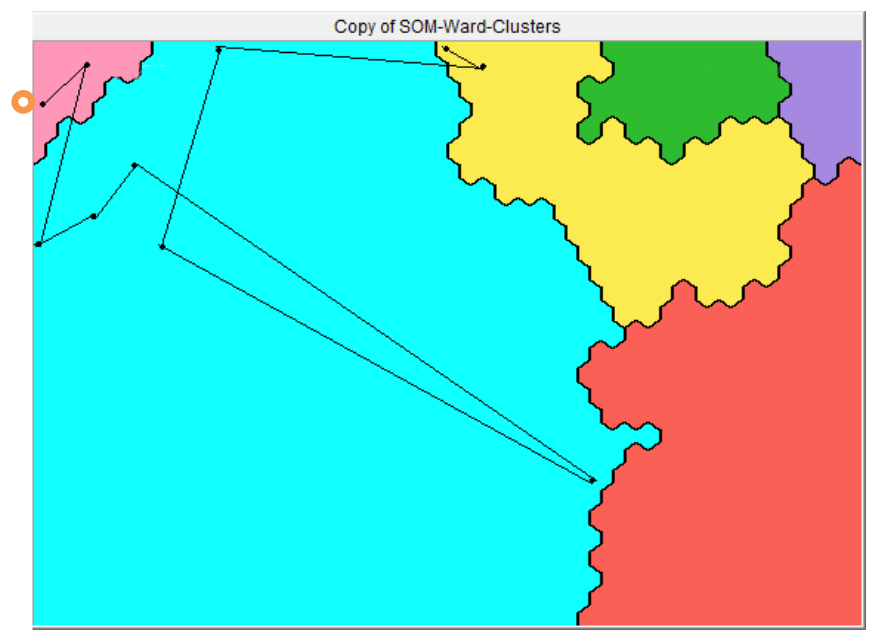

Figure 5. The trajectory of development of JSC “Oschadbank" for the period 2007-2016

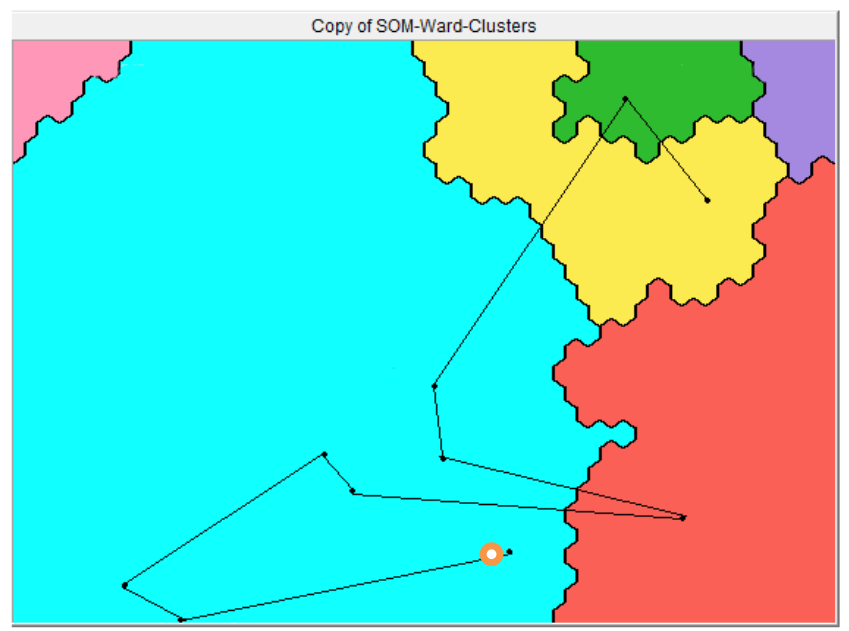

Figure 6. The trajectory of development of JSC “Ukreximbank" for the period 2007-2016

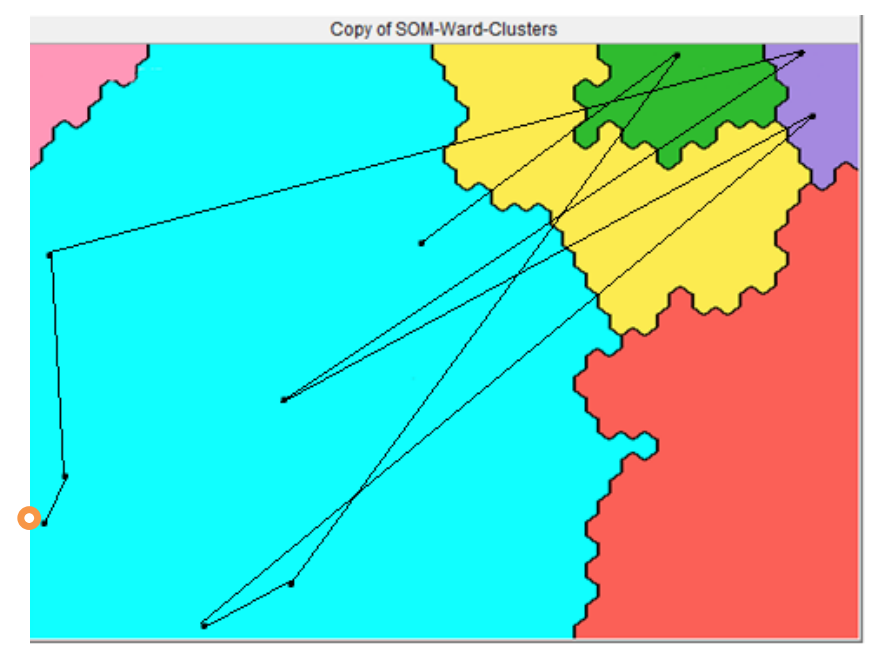

Figure 7. The trajectory of development of JSB "Ukrgasbank" for the period 2007-2016 


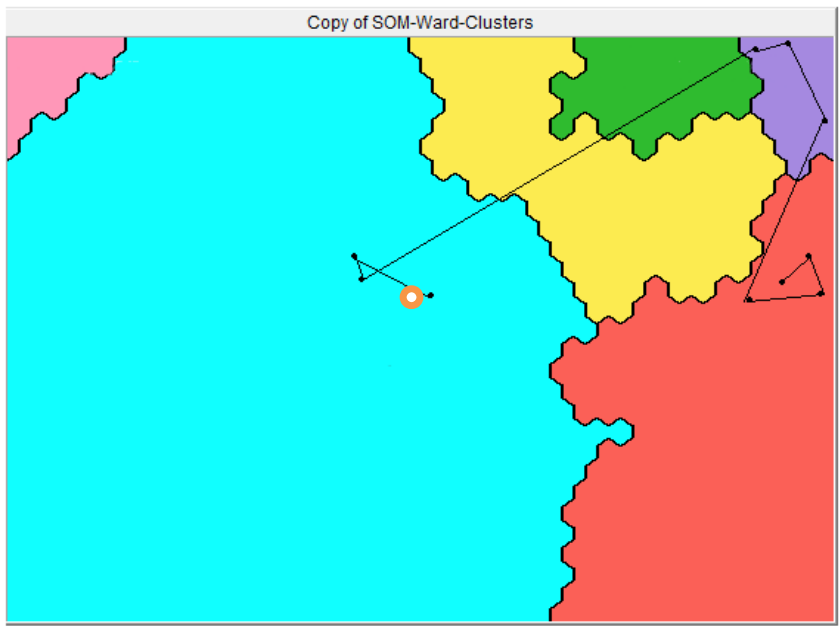

Figure 8. The trajectory of development of OJSC "Rodovid Bank" for the period 2007-2016

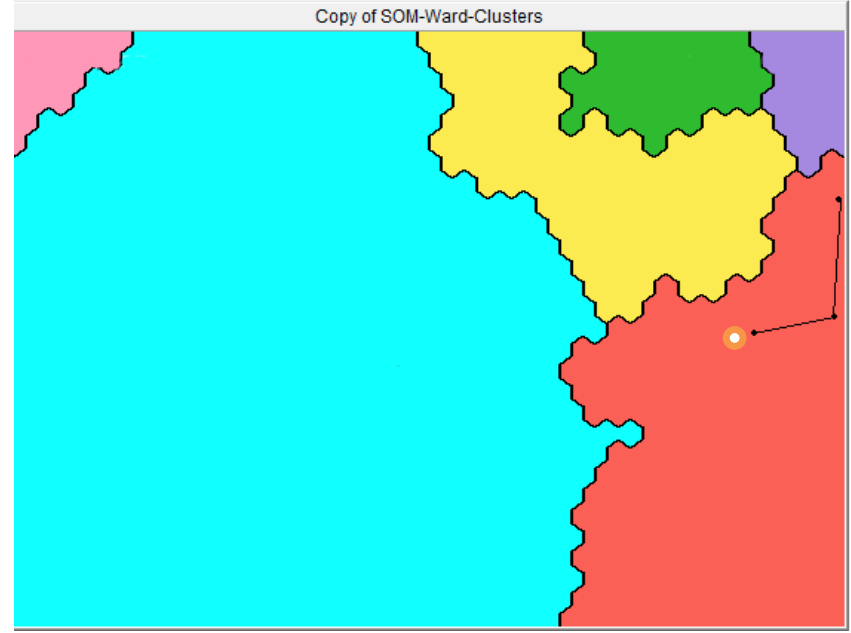

Figure 9. The trajectory of development of PJSC "Payment Center" for the period 2014-2016

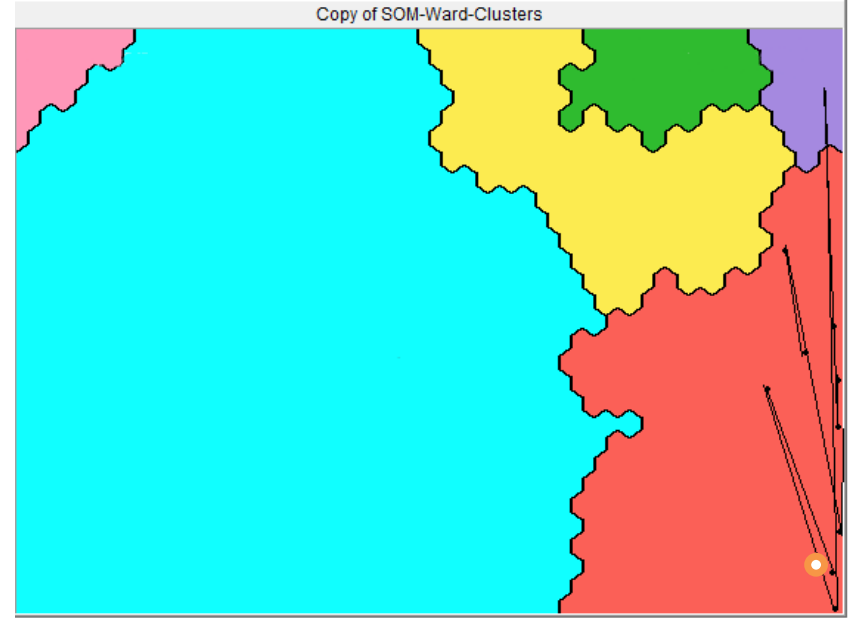

Figure 10. The trajectory of development of OJSC "The Ukrainian Bank for Reconstruction and Development" for the period 2007-2016 


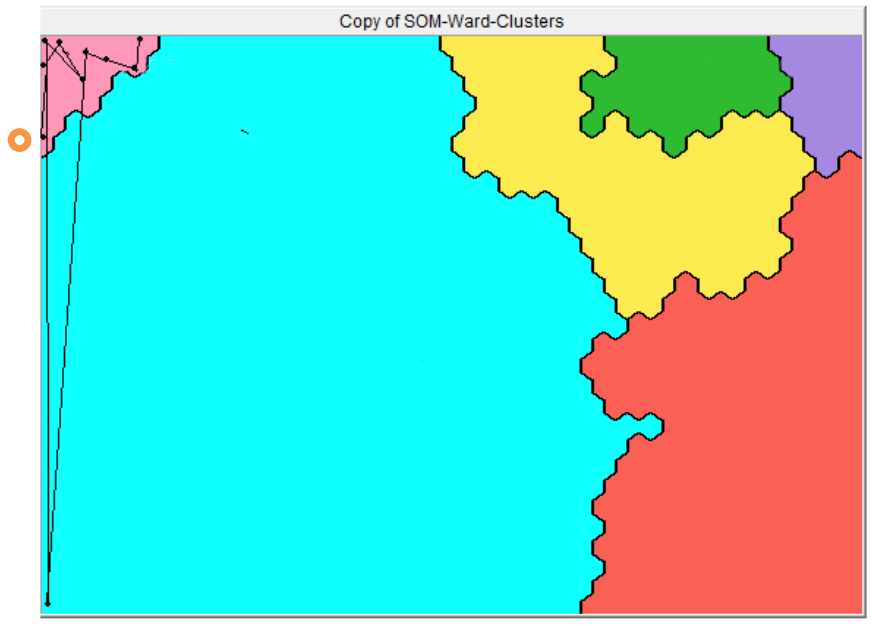

Figure 11. The trajectory of development of PJSC “CB Privatbank” for the period 2007-2016 